\title{
ARID1A wt Allele
}

National Cancer Institute

\section{Source}

National Cancer Institute. ARID1A wt Allele. NCI Thesaurus. Code C92531.

Human ARID1A wild-type allele is located in the vicinity of 1 p35.3 and is approximately 86 $\mathrm{kb}$ in length. This allele, which encodes AT-rich interactive domain-containing protein $1 \mathrm{~A}$, is involved in the modulation of chromatin structure and transcriptional regulation. Mutation of the gene is associated with ovarian clear cell carcinoma. 